\title{
CHRISTIANISMUS RENASCENS Kembali kepada Gereja Mula-mula Berdasarkan Kisah Para Rasul 2
}

\author{
Adi Putra
}

\section{A. Pengantar}

Gereja lahir melalui pemberitaan Injil. Setiap orang yang telah dipilih Tuhan, kemudian menjadi percaya melalui pemberitaan Injil atas dorongan Roh Kudus, disebut sebagai orang Kristen atau Gereja (ekklesia). Dalam konteks perjanjian, Gereja dikategorikan sebagai umat Allah yang baru, Israel yang baru. Itulah sebabnya, tugas Gereja tidak memiliki perbedaan dari umat Allah dalam PL, yakni memberitakan dan menegakkan hukum-hukum Tuhan di tengah-tengah dunia ini. Gereja dituntut menjadi terang bagi dunia di mana ia ada (Mat. 5:16).

Dalam hubungannya dengan dunia ini Gereja memiliki tanggung jawab ganda. Gereja hadir di dunia untuk hidup, melayani dan bersaksi bagi dunia. Namun Gereja juga dituntut untuk senantiasa menjaga kekudusannya - supaya tidak sama dengan dunia. Ternyata semuanya tidak berjalan mulus, karena Gereja memiliki banyak tantangan dari dunia. Puncaknya pada akhir abad ke-15 dan awal abad ke-16. Dan inilah yang menjadi cikal bakal munculnya semangat dan usaha beberapa tokoh untuk melakukan reformasi Gereja dengan spirit trisola: sola gratia, sola fide, dan sola scriptura.

Pasca-reformasi, Gereja masih saja terjebak dalam situasi yang sulit yang membuat Gereja kehilangan identitasnya sebagai umat Allah. Carl Braaten memberikan sebuah peringatan karena paham neopaganisme yang subjektif dan ahistoris ke dalam Gereja.1 Os Guinness mengamatai bahwa telah muncul masalah sekularisasi dalam Gereja. Setiap Gereja yang secara teologis dan sadar menentang sekularisme seringkali tidak menyadari bahwa ternyata mereka telah menjadi benteng pertahanan yang kokoh bagi kekristenan yang telah disekulerkan. Dan ada dua tanda yang paling terlihat dari gejala sekularisasi ini yakni pendewaan angka dan teknik.2

Adanya problem yang serius dalam Gereja juga ditegaskan oleh Larry Crabb dalam bukunya Real Church: Menjadi Orang Kristen Sejati di Tengah Dunia. Crabb menjelaskan pokok diskusi dengan seorang temannya yang cukup terkenal di kalangan Kristen. Teman Crab tersebut menceritakan kegelisahannya dan krisis spiritual yang dialaminya:

Saya sedang mengalami krisis dan bertanya-tanya apa tujuan ke Gereja. Pergi ke Gereja pernah terasa penting bagi saya. Tapi, sekarang tidak lagi. Saya bolos ke Gereja kalau saya punya alasan yang baik untuk membungkam nurani saya dan menghindari pergunjingan. Pastornya teman baik saya dan pengkhotbah yang baik. Tapi sebagian besar alasan saya ke Gereja hanya untuk memberikan contoh anak-anak saya...."3

Crabb menambahkan, "Beberapa waktu yang lalu, seorang pemimpin agama Kristen yang telah kenyang asam garam, terkenal dan disegani di kalangan evangelis ... ia berbisik: 'Anda tahu, saya benar-benar tak ingin pergi ke Gereja lagi. Tidak suka saja. Ya, saya masih pergi, tapi hanya untuk tampil, tentu saja bukan untuk kepentingan saya.... Saya pikir saya bisa melayani kerajaan Tuhan dengan lebih baik di luar Gereja”'.4

1 Carl E. Braaten, “The Gospel for a Neopagan Culture”, dalam Carl E. Braaten dan Robert W. Jenson, ed., Either/Or: The Gospel of Neopaganism, Grand Rapids, Michigan: Baker, 1995), 19-20.

2 Os Guinness, Dining With the Devil: The Megachurch Movement Flirt with Modernity, (Grand Rapids, Michigan: Baker, 1993), 49.

3 Larry Crabb, Real Church: Menjadi Orang Kristen Sejati di Tengah Dunia, (Jakarta: Gramedia, 2009), hlm.xxvii.

${ }_{4}$ Crabb, Real Church, xxvii. 
Penjelasan Crabb di atas merupakan realitas dalam kekristenan kita sekarang ini. Bukankah ada pula orang-orang Kristen yang justru tidak lagi mencintai persekutuan? Bukan hanya jemaat awam, bahkan mereka yang menyebut dirinya sebagai rohaniwan atau pelayan Tuhan justru sama sekali tidak memiliki kerinduan untuk bersekutu dengan komunitas Kristen. Apakah ini tanda bahwa seseorang belum dilahirkan kembali oleh Roh Kudus?

Secara singkat ungkapan Christianismus Renascens dapat diartikan kekristenan yang dilabirkan kembali. Ketika terjadi krisis dalam Gereja, maka para Reformator arus utama secara masif melakukan pembaruan pada ajaran dan juga praktik warga Gereja pada masa itu. Bahkan menurut pengamatan Allister E. McGrath, "Para reformator magisterial berkeyakinan bahwa hal sentral yang dibutuhkan untuk reformasi dan pembaruan adalah kembali ke ajaran dan praktik Gereja mula-mula". ${ }_{5}$ Berangkat pengamatan McGrath, dapat dikatakan bahwa Gereja mula-mula dijadikan sebagai model. Telah terjadi pergeseran dalam hal ajaran yang berkembang dalam Gereja sehingga perlu dilakukan reformasi.

McGrath menambahkan,

Para reformator menunjuk kepada vitalitas kekristenan pada periode apostolis, seperti yang disaksikan dalam PB. Dan mereka mengatakan bahwa kemungkinan sekali dan perlu sekali menghidupkan kembali semangat serta wujud dari periode yang sangat penting di dalam sejarah Gereja Kristen ini. adalah penting kembali ke PB dan belajar dari penafsirpenafsirnya yang pertama. Mereka ini merupakan bukti sah dari kekristenan, sumber asli dari ajaran dan praktik kristiani".6

Gereja pada periode apostolis menjadi model yang tepat untuk mengembalikan kasih mulamula yang mulai hilang dalam Gereja. Dan itu berarti Gereja yang dirujuk adalah Gereja seperti yang dicatat dalam pasal-pasal awal Kisah Para Rasul. Apa yang menjadi kesukaan mereka? Apa yang membuat dalam waktu yang singkat dapat berkembang dengan pesat? Dan apa rahasianya sehingga mereka senantiasa menjadi Gereja yang sehat? Pertanyaan-pertanyaan ini akan menuntun kita masuk ke dalam inti dari tulisan ini.

\section{B. Beberapa Peristiwa Penting yang Mendahului Lahirnya Gereja}

Dua hal urgen dan tidak dapat dilepaskan dari proses terbentuknya Gereja pada zaman rasul adalah peristiwa Pentakosta dan khotbah Petrus. Meskipun jauh sebelum kedua peristiwa di atas terjadi, ada dua peristiwa yang jauh lebih penting dan memiliki kesinambungan yang signifikan, yakni peristiwa kebangkitan dan kenaikan Yesus ke surga.

Kebangkitan Yesus menjadi peristiwa yang sangat penting dalam iman Kristen. Paulus menegaskan (1 Kor. 15:17): "Dan jikea Kristus tidak dibangkitkan, maka sia-sialab kepercayaan kamu dan kamu masib hidup dalam dosamu". Artinya, apabila Kristus tidak pernah bangkit maka ada dua konsekuensi yang menakutkan yang akan terjadi kepada setiap orang Kristen, yakni: (1) iman orang Kristen adalah iman yang sia-sia; dan (2) orang Kristen masih hidup dalam dosa. Apabila kebangkitan Yesus tidak pernah terjadi maka peristiwa kenaikan Yesus ke surga pasti tidak akan terjadi. Catatan penting di sini adalah "kebangkitan Yesus adalah sebuah fakta sejarah".

Peristiwa kenaikan Yesus ke surga (Kis. 1:6-11) merupakan kelanjutan dari peristiwa kebangkitan. Kenaikan ke surga memiliki tujuan ganda, yaitu supaya Roh Kudus datang menggantikan Yesus di dunia ini sebagai parakletos, dan supaya Dia pergi menyediakan tempat bagi setiap mereka yang percaya kepada-Nya. Meskipun kedua tujuan ganda ini sulit untuk dipahami dengan tuntas, namun setelah peristiwa Pentakosta, seolah-olah ada cahaya yang terang dari surga yang kemudian membukakan secara perlahan tentang misteri tersebut.

Setelah Roh Kudus turun, menghinggapi setiap murid Yesus yang berkumpul dalam ruangan (Kis. 2:1-13), mereka yang sebelumnya ketakutan dan bersembunyi, sekarang memiliki keberanian

5 Allister E. McGrath, Sejarah Pemikiran Reformasi, (Jakarta: BPK Gunung Mulia, 2011), hlm. 25.

6 Ibid., hlm. 25-26. 
untuk memberitakan Injil; hal ini ditandai dengan khotbah Petrus yang menghasilkan paling kurang 3000 orang bertobat (Kis. 2:14-47). Yang menarik dalam khotbah Petrus adalah dia mengutip beberapa nas dalam PL. Dan yang paling menonjol di situ adalah nubuat nabi Yoel, yang dipahami Petrus memiliki kaitan dengan Yesus. Petrus menyinggung semua peristiwa yang dilakukan oleh Yesus sejak pelayanan-Nya, kematian hingga kebangkitan-Nya. Itu berarti bahwa semua rangkaian peristiwa mulai kebangkitan, kenaikan ke surga hingga turunnya Roh Kudus merupakan sebuah kesatuan yang tidak dapat dipisahkan. Rangkaian peristiwa ini menjadi cikal bakal lahirnya Gereja, kemudian menjadi Israel yang baru yang akan menerima seluruh penggenapan janji Allah di dalam Yesus Kristus.

Dengan demikian, Gereja mula-mula adalah Gereja yang lahir dan hadir pada peristiwa Pentakosta, di mana peristiwa tersebut tidak dapat dipisahkan atau dilepaskan dari peristiwa kebangkitan Yesus dan kenaikan Yesus ke surga. Oleh karena semuanya masuk dalam satu rangkaian peristiwa yang tidak berdiri sendiri. Meskipun kulminasinya pada hari Pentakosta - dan ditandai dengan khotbah Petrus, maka lahirlah Gereja. Seperti apakah Gereja mula-mula itu? Berikut ini akan dibahas secara ringkas dan bersifat biblis.

\section{Gereja Mula-mula}

Dari ayat ini, ada empat hal yang mereka kemudian lakukan secara continue, bersama-sama dan serius. Ada pun keempat hal itu adalah: bertekun dalam pengajaran rasul-rasul, bertekun dalam persekutuan, berkumpul untuk memecahkan roti, dan berkumpul untuk berdoa.

\section{Gereja Mula-mula Bertekun dalam pengajaran rasul-rasul (ay.42)}

Setelah mereka menjadi percaya dan akhirnya disebut Gereja, maka melalui bimbingan para

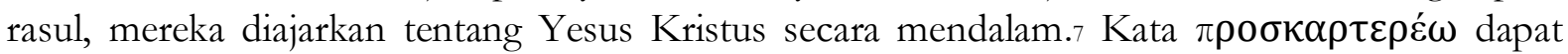
diterjemahkan "hold fast to, continue in, persevere in something".s Artinya, mereka berpegang teguh pada ajaran rasul-rasul, terus-menerus dalam ajaran rasul-rasul, dan bertekun dalam ajaran rasul-rasul.

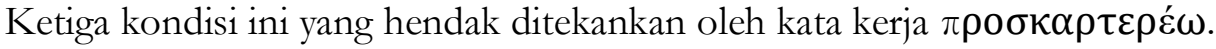

Simon J. Kistemaker mengomentari frasa ini dengan menyatakan, bahwa "They were continually devoting themselves to the apostles 'teaching' points to the fervor and dedication of the first converts to Christianity. They steadfastly turned to the apostles for instruction in Christ's gospel, for Jesus had appointed his immediate followers to be the teachers of these learners (Matt. 28:20)"..9 Jadi, menurut Kistemaker, mereka terus-menerus mengabdikan diri kepada para rasul yang "mengajar" mereka pada semangat dan dedikasi. Mereka dengan teguh berpaling kepada para rasul untuk mendapat pengajaran dalam Injil Kristus, karena Yesus telah menunjuk pengikut langsungnya untuk menjadi guru bagi mereka (bdk. Mat. 28:20).

Ajith Fernando mengamati, bahwa

The "apostles' teaching" would have been particularly important in the early church because of their special relationship to Christ and his promise to them that the Holy Spirit "will guide

7 Kistemaker pun mendukung pernyataan ini: "During his earthly ministry, Jesus taught with authority and "not as the teachers of the law' (Mrk. 1:22). Before he ascended, he delegated this authority to the apostles, who spoken in his name. Notice the double meaning of the term teaching. Extensively, the word refers to the good news of all that Jesus said and did. And intensively, the apostles were involved in the work of teaching an oral gospel to the converts, whom Luke calls disciples (learners) in Acts. We assume that this teaching was done especially at public worship services, where the apostles taught this gospel in their preaching” (Kistemaker 2007, 110). Bagi Kistemaker, secara luas ajaran rasul-rasul mengacu kepada kabar baik dari segala perkataan dan perbuatan Yesus, dan secara intensif rasulrasul disertakan dalam pekerjaan mengajar Injil secara oral untuk mengubah yang Lukas sebutkan sebagai murid dalam Kisah Para Rasul. Kita mengasumsikan bahwa pengajaran itu dilakukan pada persekutuan-persekutuan, di mana rasulrasul mengajarkan Injil ini dalam khotbah mereka.

8 Walter Bauer's, A Greek-English Lexicon of The New Testament and Other Early Christian Literature (USA: The University of Chicago, 2000), 881.

9 Simon J. Kistemaker, New Testament Commentary: Acts (Michigan: Baker Books GrandRapids, 2007), 110. 
[them] into all truth ... and ... will tell [them] what is yet to come" (John 16:13). With time the church developed a comprehensive body of teaching, so that Paul told the Ephesian elders that he had given them "the whole will and purpose of God" (20:27). At the end of his life he urged Timothy, "What you heard from me, keep as the pattern of sound teaching, with faith and love in Christ Jesus. Guard the good deposit that was entrusted to you" (2 Tim. 1:13-14). Later the church came to recognize that certain books with connections to the apostles best represented that "good deposit," and the canon of the New Testament came into being. The New Testament along with the Old Testament has become the basis for our teaching today. A key, then, for follow-through care today is to teach people the Bible.10

Bagi Fernando, "Pengajaran para rasul" akan sangat penting di Gereja mula-mula karena hubungan khusus mereka dengan Kristus dan janji-Nya kepada mereka bahwa Roh Kudus "akan membimbing mereka ke dalam semua kebenaran dan akan memberi tahu mereka apa yang akan datang" (Yoh. 16:13). Seiring waktu, Gereja mengembangkan suatu badan pengajaran yang lengkap, sehingga Paulus memberi tahu para penatua Efesus bahwa ia telah memberi mereka "seluruh kehendak dan tujuan Allah" (20:27). Di akhir hayatnya dia mendesak Timotius, agar "Penganglah segala sesuatu yang telah engkau dengar dari padaku sebagai contoh ajaran yang sehat dan lakukanlah itu dalam iman dan kasih dalam Kristus Yesus. Peliharalah harta yang indah, yang telah dipercayakan-Nya kepada kita, oleh Roh Kudus yang diam di dalam kita" (2 Tim. 1:13-14). Belakangan, Gereja mulai menyadari bahwa buku-buku tertentu dengan koneksi kepada para rasul representasi paling baik itulah "simpanan yang baik," dan kanon PB muncul. PB dan PL telah menjadi dasar bagi pengajaran kita hari ini. Dengan demikian, kunci untuk perawatan selanjutnya adalah mengajar Alkitab kepada setiap orang.

Setelah mereka menjadi murid-murid Kristus (baca: Gereja); mereka kemudian bertekun dalam pengajaran rasul-rasul. Bertekun dalam pengajaran rasul-rasul berarti secara sukarela berpaling kepada setiap perintah yang terdapat dalam Injil Kristus dan secara terus-menerus berpegang teguh kepada ajaran tersebut. Sedangkan para rasul sendiri mengajarkan Injil secara mendalam kepada mereka melalui khotbah dalam setiap persekutuan yang mereka lakukan.

\section{Gereja Mula-mula Bertekun dalam persekutuan (ay. 42)}

Selain bertekun dalam pengajaran rasul-rasul, mereka juga bertekun dalam persekutuan. Dan dalam persekutuan inilah mereka juga menerima pengajaran rasul-rasul yang berisi tentang segala sesuatu tentang Yesus. Bagi Kistemaker, fellowship ( believers demonstrated in a common bond at worship, at meals, and in the sharing of their material goods (v. 44). The Christians visibly showed their unity in Jesus Christ in the worship services, where they called one another brothers and sisters".12

Hal yang sama juga dikemukakan David G. Peterson: "The koinõn - words in Greek normally mean 'to share with someone in something' above and beyond the relationship itself, or 'to give someone a share in something'. The sharing in this case could simply refer to material blessings, as described in vv. 44-45, where we are told that the believers had everything in common (koina)".13 Baik Kistemaker maupun Peterson sepakat bahwa persekutuan dalam konteks ini adalah semangat besar yang ditunjukkan oleh Gereja mula-mula dalam sebuah ikatan umum pada ibadah, pada

10 Ajith Fernando, The NIV Application: Acts (Zondervan, Grand Rapids, Michigan: 2009), 126.

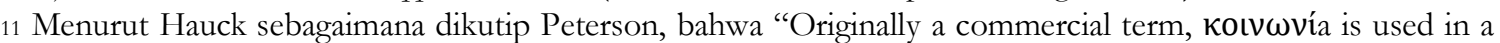
number of NT contexts to refer to the joint participation of believers in Christ (e.g., 1 Cor. 1:9) or the Holy Spirit (e.g., 2 Cor. 13:13) or their share in the demands and blessings of the gospel (e.g., Phil. 1:5). Common participation in Christ necessarily leads to a mutual fellowship among members of the Christian community (e.g., 1 Jn. 1:3)" (Peterson 2009, 160 fn.106).

12 Kistemaker, Acts, 110-1.

13 David G. Peterson, The Acts of the Apostles, (Michigan: GrandRapids, 2009), 160. 
makanan, dan berbagi dari apa yang mereka miliki (seperti dalam ayat 44-45). Orang Kristen secara nyata memperlihatkan kesatuan mereka dalam Yesus Kristus di dalam pelayanan ibadah, di mana mereka disebut saudara satu sama lain.

Menjadi jelas bahwa maksud dari frasa bertekun dalam persekutuan adalah mereka secara sukarela dan secara terus-menerus bersatu dalam ibadah, dalam makanan, saling berbagi dalam segala apa pun yang mereka miliki - untuk hal inilah mereka disebut bersaudara satu sama lain.

\section{Gereja Mula-mula Selalu Memecahkan Roti (ay. 42)}

Menurut Kistemaker, "The context, however, seems to suggest that it refers to a celebration of the Lord's Supper. In the Greek, the definite article precedes the noun bread and thus specifies that the Christians partook of the bread set aside for the sacrament of communion (compare 20:11; 1 Cor. 10:16). Also, the act of breaking bread has its sequel in the act of offering prayers (presumably in the setting of public worship)".14 Maksudnya, bagaimana pun, berdasarkan konteks sepertinya memberi kesan bahwa bertekun memecabkan roti mengacu kepada sebuah perayaan dari Perjamuan Terakhir Tuhan. Dalam bahasa Yunani, kata sandang yang mendahului kata benda bread dan demikian menetapkan bahwa orang orang Kristen mengambil bagian dari bagian-bagian roti yang dipecahkan selama sakramen dalam jemaat, seperti yang terdapat dalam 1 Korintus 10:16, “...bukankah roti yang kita pecah-pecahkan adalah persekutuan dengan tubuh Kristus?”.15

Selain itu, tindakan memecahkan roti sebagai kesinambungan dalam tindakan dari pelayanan orang-orang yang beribadah - agaknya dalam bentuk ibadah umum. Apabila Kistemaker mengaitkan tindakan memecahkan roti dengan persekutuan yang Gereja lakukan (Perjamuan Tuhan), maka lain halnya dengan Marshall yang justru melihat tindakan ini sebagai kebiasaan orang Yahudi makan terbuka, dan sungguh aneh apabila orang Kristen menilai sama tindakan Yesus pada Perjamuan Terakhir dengan ketika Dia memberi makan banyak orang, seperti yang terdapat dalam Lukas 9:16; 22:19; 24:30; Kisah Para Rasul 20:7, 11.

Meskipun istilah yang digunakan Lukas di sini sama dengan yang digunakan oleh Paulus sepertinya Lukas secara sederhana menggunakan sebuah istilah yang di Palestina pada zaman itu untuk Perjamuan Tuhan dalam bentuk yang sopan atau pantas. Marshall menambahkan, mungkin sebuah kelanjutan dari makanan-makanan yang dipegang bersama dengan kebangkitan Tuhan, tanpa beberapa hubungan yang spesifik dengan Perjamuan Terakhir dan yang Paulus pernah lakukan untuk memperingati kematian-Nya.16 Sebenarnya apa yang dikatakan Marshall hendak menegaskan bahwa tindakan ini bukan semacam sakramen akan tetapi hanya jamuan makan biasa yang dilakukan di sela-sela persekutuan - di mana mereka menikmati kebersamaan tidak hanya dalam persekutuan tetapi juga dalam hal makanan.17

14 Kistemaker, Acts, 111.

${ }_{15}$ Bruce mengatakan, "This phrase is found elsewhere in the NT only in Lk. 24:35; but cf. v. 46; 20:7, 11; 27:35; Mk. 14:22 par. Mt. 26:26 and Lk. 22:19; Lk. 24:30: 1 Cor. 1O: 16; JI :24 for xt..a<u i'igtov. Heb. piiras and Aram. $p^{\prime \prime}$ ras ("break") were used absolutely in the special sense of breaking bread at the beginning of ameal and saying grace while doing so ( cf. M. Jastrow's Dictionary, s. v. ). The Lord's Supper is probably intended: while this was celebrated in the course of a fellowship meal, the emphasis on the act of breaking the bread suggests that this "circumstance wholly trivial in itself was "the significant clement of the celebration .... Hut it could only be significant when il was a 'signum,' viz. of Christ's being broken in dealh", (Bruce, The Acts of Apostle, 132).

16 Pernyataan Marshall di atas seperti yang dikemukakannya sebagai berikut, "This is Luke's term for what Paul calls the Lord's Supper. It refers to the act with which a Jewish meal opened, and which had gained peculiar significance for Christians in view of Jesus' action at the Last Supper and also when he fed the multitudes (Lk. 9:16; 22:19; 24:30; Acts 20:7,11). It has been claimed that the thought is simply of a fellowship meal, perharps a continuation of the meals held with the risen Lord, without any specific relation to the Last Supper or the Pauline form of the Lord's Supper which celebrated his death, but it is much more likely that Luke is simply using an early Palestinian name for the Lord's Supper in the proper sense" (Marshall 2007, 83). Sebenarnya, bagi Marshall meskipun tindakan bertekun untuk memecabkan roti tidak memiliki kaitan langsung dengan Perjamuan Malam Tuhan - meskipun Lukas menggunakan istilah yang digunakan untuk the Lord's Supper, namun ketika Gereja berkumpul dan memecahkan roti tetap tindakan ini dilakukan dalam terang kebangkitan Kristus.

17 Ditambahkan oleh Fernando, "The Lord's Supper is also mentioned among the basic things done with and for the new believers (v. 42). Most Christian traditions have come to understand the Lord's Supper as a means of 
Kistemaker menambahkan, "The words breaking of bread appear within the sequence of teaching, fellowship, and prayers in worship services. Therefore, we understand the term as an early description for the celebration of Holy Communion. In liturgy of the Christian church, this celebration was and is usually accompanied by the teaching of the gospel and by prayers"..18

Jadi, karena frasa ini merupakan rangkaian dari ajaran, persekutuan, dan doa dalam pelayanan ibadah, maka istilah yang digunakan harus dipahami sebagai deskripsi awal untuk Perjamuan Kudus. Dalam liturgi Gereja, perayaan ini telah ada dan biasanya dirangkai oleh pengajaran Injil dan dirangkai oleh kegiatan berdoa. Meskipun istilah digunakan adalah istilah yang seringkali digunakan untuk Perjamuan Tuhan, akan tetapi tetap tindakan yang dimaksud di sini sangat berbeda - yakni: jamuan makan biasa yang dilakukan dalam persekutuan jemaat mula-mula.

\section{Gereja Mula-mula Bertekun dalam Doa (ay.42)}

Menurut Kistemaker, 'Literally the text has 'the prayers'. Note that here also Luke uses the definite article to describe definite prayers uttered in worship; perharps they include the formal prayers the Jews were accustomed to offer in the temple (3:1). In summary, the four elements Luke mentions in this verse (v. 42) appear to relate to public worship: apostolic teaching and preaching, fellowship of the believers, celebration of the Lord's Supper, and common prayers".19 Bagi Kistemaker, karena di sini Lukas menggunakan kata sandang maka menunjukkan bahwa kata ini menggambarkan doa-doa tertentu yang diucapkan dalam ibadah, mungkin saja termasuk doa-doa yang seringkali dipanjatkan oleh orang Yahudi di Bait Allah (3:1). Empat elemen yang disebutkan oleh Lukas dalam ayat ini tampaknya berhubungan dengan ibadah umum: pengajaran rasul dan khotbah, persekutuan orang percaya, perayaan Perjamuan Tuhan, dan doa bersama.

Hal yang senada juga dikemukakan oleh Peterson, "The plural form with the article in Greek suggests that the reference is to specific 'prayers' (KJV, NRSV, ESV) rather than to prayer in general (TNIV to prayer). In the context, this most obviously points to their continuing participation in the set times of prayer at the temple (cf. 3:1 note). However, since their eating together in household involved praising God (v. 47), they doubtless also prayed together in these groups, petitioning God about their own needs of others. Prayer was certainly an important part of their community life (e.g., 4:31) and apostolic leadership (e.g., 6:4)" ${ }_{20}$ Bagi Peterson, bentuk jamak dengan menggunakan kata sandang menunjuk kepada doa-doa yang spesifik - bukan doa secara umum. Sama seperti Kistemaker, di sini juga mengacu kepada kelanjutan dari serangkaian doa di dalam Bait Allah (3:1). Namun, karena mereka makan bersama-sama, maka tidak diragukan lagi juga mereka berdoa bersama-sama untuk mengajukan permohonan tentang kebutuhan-kebutuhan mereka kepada Tuhan. Doa itu pasti merupakan bagian yang penting dari kehidupan mereka (4:31) bersama dengan kepemimpinan rasul (6:4).

Sedangkan menurut H. V. D. Brink, "Pada persekutuan di dalam doa, tentulah juga harus diingat, di samping doa-doa di rumah, hal pergi ke Bait Suci sebelum doa pagi dan doa malam, sebagaimana juga di dalam ayat 46 diceritakan tersendiri... mengakibatkan adanya rasa hormat pada penduduk-penduduk lain Yerusalem...”.21 Maksudnya, orang Kristen mula-mula yang begitu giat

edification for believers, though there are differences among churches about the details and extent of its value. Paul said that this meal is a proclamation of that which lies at the heart of the Christian gospel, the death of Christ (1 Cor. 11:26). Does this suggest, then, that the Lord's Supper would be helpful in confirming new believers in the faith and helping them grow in grace? This is a provocative question, for new believers are often prevented from participating in the Lord's Supper until they are baptized and/or confirmed, which may take place several months after conversion. Should we then permit new Christians to participate in the Lord's Supper before baptism and/or confirmation in churches where these take place some time after conversion?" This is difficult to determine from this passage alone since the believers were baptized soon after they repented and believed. But it seems clear that, according to the Bible, we are incorporated into the body of Christ when we exercise saving faith (see Eph. 2), and that the Lord's Supper is a characteristic activity of those belonging to the body of Christ (1 Cor. 10:17). (Ajith Fernando, Acts, 126-27).

18 Kistemaker, Acts, 111.

19 Kistemaker, Acts, 111.

20 Peterson, The Acts of The Apostles, 162.

21 H.v. d. Brink, Tafsiran Alkitab: Kisah Para Rasul, (Jakarta: BPK Gunung Mulia, 2008), 46. 
berdoa tidak hanya merasakan kebaikan dan kemurahan Tuhan dalam kehidupan iman mereka, melainkan mereka juga disenangi oleh orang-orang Yerusalem, meskipun seperti yang kita ketahui mereka begitu membenci para pengikut Kristen.22

Dengan demikian dapat dilihat bahwa sebagai bagian dari rangkaian dari persekutuan mereka, di dalamnya mereka juga memanjatkan doa kepada Tuhan. Dan doa yang dimaksud di sini adalah doa-doa tertentu, mungkin menyangkut tentang kebutuhan atau pun hal-hal yang urgen dari kehidupan mereka.

\section{Gereja Mula-mula Giat Bersaksi}

Pemahaman bahwa Gereja mula-mula adalah Gereja yang suka dan giat bersaksi diperoleh dari Kisah Para Rasul 2:47. Di situ dikatakan, "Dan mereka disukai semua orang. Dan tiap-tiap hari Tuban menambah jumlah mereka dengan orang yang diselamatkan". Ada dua indikator yang kuat menegaskan mereka giat bersaksi dalam ayat ini, yakni: mereka disukai dan Tuhan menambah jumlah mereka. C. K. Barret mengatakan, "Meanwhile the Lord added (for1 rpocrn6evaL see on v. 41) to their numbers. The church's 'continued existence ... implies the constant "adding" of men to it ... Seen from below, this means that in obedience to the Word of God and under the compulsion of the Holy Spirit they wish to enter into and belong to it in recognition of the change in the times and in their own lives.' But also the church 'has

no reason for existence apart from the kingdom of God, the call and Word of the Lord and the power of the Holy Ghost".23

Meskipun Barret tidak secara gamblang menjelaskan bahwa penambahan jumlah yang dialami oleh Gereja mula-mula andil dari mereka yang giat bersaksi, namun dia hendak menegaskan bahwa dengan ketaatan kepada Firman Tuhan dan pimpinan Roh Kudus membuat kemudian perubahan dalam kehidupan mereka. Di mana kemudian perubahan tersebut dipahami sebagai perubahan yang memberikan mereka keberanian untuk bersaksi tentang Injil Kristus.

F. F. Bruce juga memberikan komentar yang identik dengan Barret. Keduanya lebih menekankan kepada tindakan aktif menarik petobat-petobat baru dan masuk menjadi anggota Gereja yang baru. Bruce berkomentar: "The Lord himself reserves the prerogative of adding new members to his community; it is for his people to welcome those whom he has received (Rom. 15 :7)".24 Pada intinya, Bruce mau mengatakan, Tuhan sendiri memiliki hak prerogatif untuk menambahkan anggota baru kepada komunitasnya; adalah agar umat-Nya menyambut orangorang yang telah dia terima (Rm. 15: 7).

Charles H. Talbert memberikan penjelasan yang cukup menarik tentang bagian ini. Menurutnya,

The results of the Pantecostal events as described in Acts 2 are primarily two. (a) Evangelistic outreach results from the empowered witness of the apostles (v. 41: three thousand converts; $\mathrm{v} 47 \mathrm{~b}$ ). (b) The establishment of a new kind of community results from the empowering and the outreach. It includes the nurture of the new converts (vv. 42, 46), corporate worship (vv. 42,46 ), and unity manifested in a sharing of possesions (vv. 44-45). Underlying both results is the empowered witness of the apostles (v. 43 cf. 5:32 where such manifestations of the Spirit are regarded as a second witness testifying to the veracity of the apostles' words). In

22 Ditambahkan oleh Fernando, "We have already said how important prayer is to the life of the church. What verse 42 reminds us is that we must get people into the life of prayer soon so that it becomes natural to them. They must imbibe it into their lifestyle by participating in its vibrant use in the life of the church." (Fernando, Acts, 127).

23 C. K. Barret, A Critical And Exegetical Commentary on the Acts of the Apostle. Vol. 1 (Scotland: T\&.T Clark, 1994), 172.

24 F.F. Bruce, The Acts of Apostle:Greek Text with Introduction and Commentary, (Michigan: William B. Eerdmans Publishing Company Grand Rapids, 1990), 133. 
the narrative plot of Acts so far, the emphasis is that as empowering follows petition so evangelism and church unity follow Pentecost.25

Jadi, menurut Talbert, hasil dari peristiwa Pantekosta seperti yang dijelaskan dalam Kisah 2 pada dasarnya adalah dua, yakni: (a) Hasil penjangkauan penginjilan dari saksi para rasul yang diberdayakan (ay. 41: tiga ribu orang yang dipertobatkan; ay. 47b). (b) Pembentukan komunitas jenis baru hasil dari pemberdayaan dan penjangkauan. Ini termasuk pengasuhan para petobat baru (ay. 42, 46), ibadah perusahaan (ay. 42, 46), dan kesatuan yang diwujudkan dalam suatu pembagian kepemilikan (ay. 44-45). Mendasari kedua hasil adalah kesaksian para rasul yang diberdayakan (ay. 43 lih. 5:32 di mana manifestasi Roh seperti itu dianggap sebagai saksi kedua yang bersaksi tentang kebenaran kata-kata para rasul). Dalam alur cerita Kisah Para Rasul sejauh ini, penekanannya adalah bahwa ketika memberdayakan mengikuti petisi, maka penginjilan dan kesatuan Gereja akan mengikuti Pentakosta. Dengan demikian, penjelasan Talbert ini cukup memberikan sebuah indikasi yang kuat bahwa Gereja mula-mula adalah Gereja yang giat bersaksi. Dan hal ini tidak dapat dilepaskan dari kuasa dan keberanian yang mereka miliki setelah Roh Kudus turun melalui peristiwa Pentakosta.

\section{Kesimpulan}

Berikut ini dideskripsikan beberapa kesimpulan:

Pertama, Gereja masa kini yang telah kehilangan kasih mula-mula seyogianya menjadikan Gereja mula-mula sebagai model untuk reformasi dan memperbaiki setiap pelanggaran dan konspirasi yang terjadi dalam Gereja. Itulah sebabnya, Christianismus Renascens menjadi tema yang cukup baik, karena semangatnya adalah hendak mengembalikan Gereja kepada ajaran, prinsip dan gaya hidup Gereja yang sebenarnya (yakni: ajaran rasuli).

Kedua, Gereja mula-mula adalah Gereja yang lahir pada hari Pentakosta atau yang lebih dikenal dengan hari turunnya Roh Kudus. Hal itu ditandai dengan khotbah Petrus yang membuat Roh Kudus mempertobatkan setidaknya 3000 orang. Akan tetapi perlu untuk digarisbawahi bahwa peristiwa turunnya Roh Kudus bukanlah peristiwa tunggal, melainkan peristiwa puncak dari rangkaian peristiwa sebelumnya, seperti: kebangkitan Yesus dan kenaikan Yesus ke surga.

Ketiga, ada pun gaya hidup dan prinsip hidup Gereja mula-mula yang dijadikan model adalah Gereja mula-mula bertekun dalam pengajaran rasul-rasul, bertekun dalam persekutuan, selalu memecahkan roti, bertekun dalam doa dan giat bersaksi.

\section{Literatur}

Barret, C. K. A Critical And Exegetical Commentary on the Acts of The Apostle. Vol. I. Scotland: T\&.T Clark, 1994.

Bauer's, Walter. A Greek-English Lexicon of the New Testament and Other Early Christian Literature. USA: The University of Chicago, 2000.

Braaten Carl E. dan Robert W. Jenson, ed. Either/Or: The Gospel of Neopaganism. Grand Rapids, Michigan: Baker, 1995.

Brink, H.v. d. Tafsiran Alkitab: Kisah Para Rasul. Jakarta: BPK Gunung Mulia, 2008.

Bruce, F. F. The Acts of Apostle: Greek Text with Introduction and Commentary. Grand Rapids, Michigan:

William B. Eerdmans Publishing Company, 1990.

Crabb, Larry. Real Church: Menjadi Orang Kristen Sejati di tengah Dunia. Jakarta: Gramedia, 2009.

Fernando, Ajith, The NIV Application: Acts. Grand Rapids, Michigan: Zondervan, 2009.

Guinness, Os. Dining With the Devil: The Megachurch Movement Flirt with Modernity. Grand Rapids, Michigan: Baker, 1993.

Kistemaker, Simon J. New Testament Commentary: Acts. Grand Rapids, Michigan: Baker Books, 2007.

${ }_{25}$ Charles H. Talbert, Reading Acts: A Literary and Theological Commentary on The Acts of The Apostles, (Macom, Georgia: Smith \& Helwysh Publishing, 2005), 33-34. 
McGrath, Allister E. Sejarah Pemikiran Reformasi. Jakarta: BPK Gunung Mulia, 2011.

Peterson, David G. The Acts of The Apostles. Michigan: GrandRapids, 2009.

Talbert, Charles H. Reading Acts: A Literary and Theological Commentary on the Acts of the Apostles. Macom, Georgia: Smith \& Helwysh Publishing, 2005. 